\title{
Transformasi Hujan Bulan Juni Karya Sapardi Djoko Damono
}

\author{
Mulyo Hadi Purnomo ${ }^{1}$, Untung Kustoro ${ }^{2}$ \\ Fakultas Ilmu Budaya, Universitas Diponegoro \\ mulyohp@yahoo.com ${ }^{1}$, untung.kustoro@gmail.com²
}

\begin{abstract}
The process of literary transformation is becoming a trend, especially from novel to film. The process of transformation is relatively rare in poetry into other literary works, let alone done by the same author as a poem into a novel Rain of June by Sapardi Djoko Damono. With the approach of transformation theory and comparison method found similarities and differences. Additions, replacements, and deletions that occur from poetry to novel. This change occurs because the constituent structure of two different works. However, the overall theme, mandate, and essence of both literary works are the same.
\end{abstract}

Keywords: Transformation, poem, novel, replacement, replacement, deletion.

\section{Intisari}

Proses transformasi sastra sedang menjadi trend, terutama dari novel menjadi film. Proses transformasi relatif jarang terjadi pada puisi menjadi karya sastra lain, apalagi dilakukan oleh penulis yang sama seperti puisi menjadi novel Hujan Bulan Juni karya Sapardi Djoko Damono. Dengan pendekatan teori transformasi dan metode perbandingan ditemukan kesamaan dan perbedaan. Penambahan, penggantian, dan pelesapan yang terjadi dari puisi ke novel. Perubahan ini terjadi karena struktur penyusun dari dua karya yang berbeda. Namun, secara keseluruhan tema, amanat, dan inti dari kedua karya sastra adalah sama.

Kata Kunci: Transformasi, puisi, novel, penggantian, penggantian, pelesapan.

\section{Pendahuluan}

Perubahan bentuk karya seni dari satu jenis ke jenis yang lain nampaknya sedang menjadi trend saat ini. Kecenderungan yang paling menyolok adalah perubahan dari novel menjadi film. Hal ini bisa dimaklumi karena memang keduanya sama-sama memiliki elemen utama yang sama, yaitu cerita. Hanya saja pada pengolahan cerita bisa jadi akan berbeda karena medium utama penyampaiannya yang berbeda; Novel memanfaatkan bahasa kata-kata sedang film menggunakan gambar. Hal lain yang menjadi pembeda adalah faktor penceritaannya: jika novel relatif tak berbatas sedang film cenderung memeiliki keterbatasan durasi, khususnya pada film komersial. Eneste (1991:61-62) menjelaskan bahwa pengurangan atau pemotongan pada unsur cerita sastra dilakukan karena beberapa hal, yaitu: (1) anggapan bahwa adegan maupun tokoh tertentu dalam karya sastra tersebut 
tidak diperlukan atau tidak penting ditampilkan dalam film. Selain itu, latar cerita dalam novel tidak mungkin dipindahkan secara keseluruhan ke dalam film, karena film akan menjadi panjang sekali. Oleh karena itu, latar yang ditampilkan dalam film hanya latar yang memadai atau yang penting-penting saja. Hal tersebut tentu saja tidak lepas dari pertimbangan tujuan dan durasi waktu penayangan. (2) Alasan mengganggu, yaitu adanya anggapan atau alasan sineas bahwa menghadirkan unsur-unsur tersebut justru dapat mengganggu cerita di dalam film. (3) Adanya keterbatasan teknis film atau medium film, bahwa tidak semua bagian adegan atau cerita dalam karya sastra dapat dihadirkan di dalam film. (4) Alasan penonton atau audiens, hal ini juga berkaitan dengan persoalan durasi waktu.

Dalam tradisi seni, proses-proses perubahan sendiri memiliki beberapa sebutan, yaitu transformasi, alih wahana, dan ekranisasi. Dari beberapa penyebutan tersebut ada yang membedakan karena sumber dan jenis perubahannya namun ada pula yang menyebutnya dengan pengertian yang direduksi dengan sebutan umum transformasi.

Menurut KBBI (edisi 4: 2008), transformasi adalah perubahan rupa (bentuk, sifat, fungsi). Selanjutnya, Nurgiyantoro (2007:18) mengemukakan, transformasi adalah perubahan suatu hal atau keadaan. Bentuk perubahan, ada kalanya berubah kata, kalimat, struktur, dan isi karya sastra (novel) itu sendiri. Selain itu transformasi juga bisa dikatakan, pemindahan atau pertukaran suatu bentuk ke bentuk lain, yang dapat menghilangkan, memindahkan, menambah, atau mengganti unsur seperti transformasi novel ke film. Bermacam-macam alasan mendasari proses transformasi dari novel ke film. Alasan-alasan tersebut antara lain karena sebuah novel sudah terkenal, sehingga masyarakat pada umumnya sudah tak asing lagi dengan cerita novel itu. Pada akhirnya, ketidakasingan tersebut mendukung aspek komersil. Alasan terakhir adalah karena ide cerita novel dianggap bagus oleh masyarakat dan penulis skenario film. Munculnya fenomena pengadaptasian novel ke bentuk film merupakan perubahan substansi dari wacana yang memunculkan istilah ekranisasi.

Alih wahana adalah perubahan dari satu jenis kesenian ke jenis kesenian lain. Karya sastra tidak hanya bisa diterjemahkan yakni dialihkan dari satu bahasa ke bahasa lain, tetapi juga dialihwahanakan, yakni diubah menjadi jenis kesenian lain. Kegiatan di bidang ini akan menyadarkan kita bahwa sastra dapat bergerak kesana kemari, berubahubah unsur-unsurnya agar bisa sesuai dengan wahananya yang baru (Damono, 
2005:96). Selanjutnya, Damono (2005:106-107) menyatakan bahwa, karya sastra juga bisa digubah menjadi nyanyian dan lukisan, atau sebaliknya. Di Indonesia kita kenal istilah musikalisasi puisi, yakni usaha untuk mengubah puisi menjadi musik. Kegiatan semacam itu sudah sejak lama terjadi dimana-mana, baik yang menyangkut lagu populer maupun klasik. Sebagai lagu, ia termasuk seni musik yang nada-nadanya bisa saja dimainkan secara instrumental tanpa menyertakan liriknya. Sementara itu lirik tersebut tetap saja berupa puisi jika dipisahkan dari lagunya. Bukan hanya itu, alih wahana juga bisa terjadi dari film menjadi novel atau bahkan puisi yang lahir dari lukisan atau lagu dan sebaliknya. Alih wahana novel ke film misalnya, tokoh, latar, alur, dialog, dan lain-lain harus diubah sedemikian rupa sehingga sesuai dengan keperluan jenis kesenian lain.

Damono (2005:109) menyatakan penyaduran karya sastra ke bentuk yang berbeda dengan sumbernya, puisi menjadi prosa atau sebaliknya, dan selanjutnya tanpa mengadakan perubahan atas beberapa unsurnya seperti latar, penokohan, dan alur. Dalam sastra Jawa modern jenis kegiatan ini yang paling banyak dilakukan.

Dalam kajian ilmiah, transformasi dari karya sastra ke bentuk film lebih dikenal dengan sebutan ekranisasi. Istilah ini berasal dari bahasa Prancis, écran yang berarti 'layar'. Ekranisasi adalah pelayar putihan atau pemindahan atau pengangkatan sebuah novel ke dalam film. Menurut Eneste (1991:60-61) ekranisasi adalah pelayarputihan atau pemindahan atau pengangkatan sebuah novel ke dalam film (ecran dalam bahasa Perancis berarti layar). Dalam prosesnya, perubahan dari novel ke layar putih bisa mengalami penciutan, penambahan dan perubahan dengan sejumlah variasi. Alat utama dalam novel adalah kata-kata, segala sesuatu disampaikan dengan kata-kata. Cerita, alur, penokohan, latar, suasana, dan gaya sebuah novel dibangun dengan kata-kata. Pemindahan novel ke layar putih, berarti terjadinya perubahan pada alat-alat yang dipakai, yakni mengubah dunia kata-kata menjadi dunia gambar-gambar yang bergerak berkelanjutan. Sebab di dalam film, cerita, alur, penokohan, latar, suasana dan gaya diungkapkan melalui gambargambar yang bergerak berkelanjutan.

Eneste (1991:60-61) menyatakan bahwa pada proses penggarapannya pun terjadi perubahan. Novel adalah kreasi individual dan merupakan hasil kerja perseorangan. Seseorang yang mempunyai pengalaman, pemikiran, ide, atau hal lain, dapat saja menuliskannya di atas kertas dan jadilah sebuah novel yang siap untuk dibaca atau tidak dibaca orang lain. Tidak demikian pembuatan film. Film merupakan hasil kerja gotong 
royong. Bagus tidaknya sebuah film, banyak bergantung pada keharmonisan kerja unit-unit di dalamnya: produser, penulis skenario, sutradara, juru kamera, penata artistik, perekam suara, para pemain, dan lain-lain. Dengan kata lain, ekranisasi berarti proses perubahan dari sesuatu yang dihasilkan secara individual menjadi sesuatu yang dihasilkan secara bersama-sama (gotong-royong).

Pada umumnya perubahan dilakukan dari novel ke film. Relatif jarang perubahan dilakukan dari puisi ke fiksi atau sebaliknya. Apalagi perubahan tersebut dilakukan oleh penulis yang sama. Hal yang menarik terjadi pada Hujan Bulan Juni. Karya yang ditulis oleh Sapardi Djoko Damono mulanya lebih populer dikenal masyarakat sebagai puisi namun oleh penulisnya sendiri diubah menjadi sebuah novel, dan pada tahap berikutnya diubah oleh orang lain (sutradara) menjadi sebuah karya film. Meskipun ditulis oleh penulis yang sama, apakah Hujan Bulan Juni mengalami perubahan mendasar sebagaimana dituliskan dalam teori.

Puisi Hujan Bulan Juni merupakan karya penyair Sapardi Djoko Damono yang ditulis pada 1989. Setelah beberapa tahun karya tersebut diterbitkan oleh Grasindo pada tahun 1994 dan dicetak ulang pada tahun 2013 sebagai buku kumpulan puisi (edisi 1994 yang diperkaya dengan sajak-sajak sejak 1959). Selain itu puisi " $H B J$ ” juga dibuat dalam bentuk musikalisasi yang dibawakan oleh Duet Reda Gaudiamo dan Ari Malibu dengan judul album Hujan Bulan Juni (1990). Selain ditransformasikan dalam bentuk musikalisasi (lagu), juga bertransformasi menjadi komik yang diciptakan oleh Mansyur Daman. Kemudian dengan kreativitas Sapardi Djoko Damono puisi tersebut mampu bertransformasi menjadi sebuah novel dengan judul Hujan Bulan Juni (selanjutnya disingkat $H B J$ ). Novel $H B J$ terbit pertama kali pada Juni 2015 oleh Gramedia, kemudian novel setebal 135 halaman ini telah banyak diperbincangkan dalam dunia sastra khususnya dalam hal transformasi. Tahun 2017 muncullah transformasi Hujan Bulan Juni menjadi sebuah film layar lebar karya sutradara Reni Nurcahyo dan Hestu Saputra.

Penelitian ini termasuk dalam penelitian pustaka (library research) karena keseluruhan data diambil dari sumber data yang berupa teks-teks dalam puisi " $H B J$ " dan novel $H B J$. Ruang lingkup penelitian ini adalah proses transformasi dari kedua karya sastra serta persamaan dan perbedaan dari keduanya. Objek material dari penelitian ini adalah puisi dan novel HBJ karya Sapardi Djoko Damono. Sedangkan objek formalnya adalah transformasi bentuk puisi dan novel $H B J$ karya Sapardi Djoko Damono. 
Pembicaraan mengenai alih wahana tidak akan terlepas dari konsep peralihan, dalam arti tertentu alih wahana akan memberikan keleluasaan pada kita untuk menemukan dan menguraikan masalah yang sebenarnya tidak disadari pentingnya. Beberapa istilah yang bisa dikenal dalam kaitannya dengan kegiatan atau hasil transformasi antara lain, ekranisasi, musikalisasi, dramatisasi, dan novelisasi. Ekranisasi berasal dari bahasa Prancis, Iecran, yang berarti layar; jadi istilah itu mengacu ke alih wahana dari suatu benda seni (biasanya yang termasuk sastra) ke film. Musikalisasi umumnya mencakup pengalihan puisi menjadi musik; dramatisasi adalah pengubahan dari karya seni ke drama; novelisasi adalah kegiatan mengubah film atau karya sastra lain menjadi novel (Damono, 2014:15).

Dalam perkembangan kegiatan kesenian, sangat lumrah suatu jenis kesenian mengambil kesenian lain sebagai sumbernya. Proses itu sebenarnya sudah berlangsung entah sejak kapan, yang hanya baru-baru ini saja mendapat perhatian-terutama di dunia akademik-sebagai bahan studi dan penelitian. Dalam perkembangan dan arus komunikasi dan media yang semakin canggih, proses tersebut jelas semakin menonjol dalam kegiatan kreatif seniman. Dewasa ini sangat terasa satu jenis kesenian semakin membutuhkan jenis kesenian lain, baik sebagai acuan maupun-dan terutama-dalam kaitannya dengan proses intertekstual. Proses tersebut penting disimak justru karena di zaman teknologi yang menghasilkan komunikasi canggih ini berbagai jenis teks bebas bergerak ke sana-ke mari membentuk teks "baru".

Sebuah teks apa pun wujudnya, pada hakikatnya "hanyalah" merupakan himpunan teks-teks lain yang ada sebelumnya. Kaitan-kaitan antara teks-teks itulah yang disusun menjadi makna oleh penerimanya: pembaca atau penonton (Damono. 2011-b). Interteks adalah konsep penting yang berkaitan dengan transformasi. Yang menjadi tumpuan dalam transformasi adalah pengambilan satu jenis kesenian sebagai sumber atau acuan jenis kesenian lain. Tentu saja yang diambil bukan wahana itu sendiri tetapi apa yang terkandung di dalamnya.

Transformasi membuktikan sejauh mana jenis karya sastra puisi dapat berubah menjadi novel dengan judul yang sama. Karya sastra tersebut dianalisis menggunakan teori struktur-fiksi, dan dicari persamaan dan perbedaannya menggunakan pendekatan transformasi, maka dengan menggunakan pendekatan transformasi inilah bisa ditarik 
kesimpulan sampai sejauh mana perubahan yang dilakukan Sapardi Djoko Damono dalam mengembangkan sajak-sajak menjadi novel dengan judul $H B J$.

Diteorikan dalam banyak literatur bahwa karya sastra merupakan sebuah struktur yang utuh. Struktur berarti bahwa karya sastra itu merupakan susunan unsur-unsur yang bersistem, yang antara unsur-unsurnya terjadi hubungan yang timbal balik, saling menentukan. Jadi, kesatuan unsur-unsur dalam sastra bukan hanya berupa kumpulan atau tumpukan hal-hal atau benda-benda yang berdiri sendiri-sendiri, melainkan hal-hal itu saling terikat, saling berkaitan, dan saling bergantung. Dalam pengertian struktur ini terlihat adanya rangkaian kesatuan yang meliputi tiga ide dasar, yaitu ide kesatuan, ide transformasi, dan ide diri sendiri (self-regulation) (Piaget melalui Hawkes, 1978:16).

Pertama, struktur itu merupakan kesatuan yang bulat, yaitu bagian-bagian yang membentuknya tidak dapat berdiri sendiri di luar struktur itu. Kedua, struktur itu berisi gagasan transformasi dalam arti bahwa struktur itu tidak statis. Struktur itu mampu melakukan prosedur-prosedur transformasional, dalam arti bahan-bahan baru diproses dengan prosedur dan melalui prosedur itu. Ketiga, struktur itu mengatur diri sendiri, dalam arti struktur itu tidak memerlukan pertolongan bantuan dari luar dirinya untuk mengesahkan prosedur transformasinya. Jadi, setiap unsur itu mempunyai fungsi tertentu berdasarkan aturan dalam struktur itu. Setiap unsur mempunyai fungsi tertentu berdasarkan letaknya dalam stuktur.

\section{Metode Penelitian}

Mengacu pada rumusan masalah serta tujuan penelitian ini merupakan penelitian kepustakaan dengan objek puisi dan novel $H B J$ karya Sapardi Djoko Damono. Penelitian ini akan mengungkap struktur karya sastra yang mengalami proses transformasi. Unsurunsur karya sastra akan dibandingkan sehingga akan didapatkan persamaan dan perbedaan dari kedua karya sastra.

Mengingat penelitian ini adalah penelitian pustaka yang mendasarkan objeknya dari data tekstual yang membutuhkan analisis deskriptif maka penelitian ini bersifat kualitatif. Karena itu, metode yang bersifat memaparkan gambaran yang secermat mungkin mengenai individu, keadaan bahasa, gejala atau kelompok tertentu. Moleng (2010:11) menyatakan bahwa data yang dikumpulkan dalam metode deskriptif adalah berupa katakata, gambar, dan bukan angka-angka. Hal itu disebabkan oleh adanya penerapan metode 
kualitatif. Selain itu, semua yang dikumpulkan berkemungkinan menjadi kunci terhadap apa yang sudah diteliti.

\section{Hasil dan Pembahasan}

\section{Transformasi Hujan Bulan Juni: dari Puisi menjadi Novel}

Perubahan struktur yang sangat mendasar terjadi pada novel $H B J$. Pada karya aslinya yang berupa puisi yang sifatnya sangat terbatas membuat pembaca memiliki imajinasi masingmasing sesuai interpretasi membacanya. Ketika proses transformasi terjadi pada puisi menjadi novel, maka perbedaan struktur keduanya akan terlihat sangat jelas. Perbedaan struktur tersebut disebabkan oleh perbedaan bentuk, aturan dalam puisi, dan aturan dalam novel sendiri.

Puisi menggunakan bahasa yang dipadatkan, dipersingkat, dan diberi irama dengan bunyi bahasa yang padu serta pemilihan kata-kata kiasan yang mendalam (imajinatif). Kata-kata dalam puisi benar-brenar terpilih agar memiliki kekuatan pengucapan. Meskipun puisi itu singkat dan padat namun memiliki kekuatan. Setiap kata-kata dalam puisi mewakili makna yang lebih luas dan lebih banyak. Karena itulah, kata-kata dalam puisi dicarikan konotasi atau makna tambahannya dan dibuat bergaya dengan bahasa figuratif.

Novel berbentuk naratif sehingga seluruh ceritanya digambarkan dengan deskripsi yang jelas dari pengarang. Novel memungkinkan cerita dipaparkan secara panjang lebar dan detel. Penulis mengambarkan dengan jelas tokoh, watak, dan setting dengan narasi sehingga pembaca mempunyai kebebasan untuk menduga-duga gambaran tokoh, watak, dan setting sesuai dengan imajinasi sendiri. Alur terbentuk sesuai jalan cerita berdasarkan paparan pencerita yang disusun oleh penulis.

Perubahan bentuk dari karya sastra puisi menjadi novel ini memang terbilang unik dan jarang terjadi dalam karya sastra. Karena dalam puisi tidak pernah terlihat jelas tokoh, watak, dan setting yang digambarkan dengan bahasa imajinatif. Sedangkan dalam novel digambarkan dengan jelas dan detel semua hal itu, pembaca tinggal membentuk imajinasinya sesuai jalan cerita. Puisi bersifat imajinatif sedangkan dalam novel bersifat naratif.

Perubahan dari puisi menjadi novel jelas terlihat pada penambahannya, dengan acuannya adalah puisi sebagai karya hasil dari transformasi. Penambahan yang terjadi berupa tokoh, watak, dan setting yang digambarkan dengan jelas. Perubahan yang 
ditimbulkan akibat transformasi dari puisi menjadi novel $H B J$ meliputi penambahan, penggantian, dan pelesapan.

Persamaan dari kedua karya sastra juga terlihat karena memang dari segi pengarang merupakan orang yang sama. Sedangkan dari karyanya sendiri ketika kita membaca puisi dan novel maka imajinasi dan interpretasi yang ditimbilkan akan sama, bahwa novel $H B J$ merupakan transformasi dari puisi " $H B J$ ". Kesamaan ditunjukkan dari hujan dan bunga pada puisi yang diceritakan pada novel sebagai Sarwono dan Pingkan. Sedangkan dari segi lain berupa alur, setting, tokoh tambahan, dan sudut pandang merupakan bagian yang menyempurnakan cerita dalam sebuah novel yang utuh.

\section{Penambahan}

Melalui pembacaan puisi yang dilakukan penulis serta dengan imajinasi dari penulis dihasilkan gambaran dari puisi " $H B J$ " karya Sapardi Djoko Damono. Pertama akan diuraikan imajinasi pembaca, kemudian menjelaskan tokoh yang diimajinasikan, dan setting kejadian yang mungkin tergambarkan dari imajinasi pembacaan puisi tersebut.

Puisi " $H B J "$ karya Sapardi Djoko Damono secara keseluruhan memberikan gambaran pada peristiwa yang datang pada waktu yang tidak tepat. Bulan Juni adalah musim kemarau saat di mana seharusnya hujan tidak datang. Peristiwa itu mengungkapkan kerinduan seorang tokoh terhadap tokoh lain yang dicintainya dirahasiakannya rintik rindunyakkepada pohon berbunga itu yang disertai dengan ketabahan, kebijakan, dan kearifan dari tokoh yang tidak lain dan tidak bukan dapat menjadikan watak tokoh dalam novel. Tabah karena dapat merahasiakan rintik rindunya kepada tokoh yang ia cintai pohon berbunga; bijak karena mampu menghapus jejak-jejak kakinya yang ragu-ragu di jalan yang dapat diartikan sebagai perjalanan yang mengambarkan setting dalam novel; $\underline{\text { arif }}$ karena mampu membiarkan hal-hal yang tidak terucapkan untuk diserap oleh akar pohon berbunga itu.

Penambahan dari puisi menjadi novel terjadi pada: a. tokoh (kuantitas dan kualitas b. alur (kronologis dan kausalitas) c. sudut pandang

Dalam puisi tokoh yang terimajinasikan dalam pikiran pembaca adalah sebuah hujan dan pohon berbunga. Terlihat jelas pada bait puisi berikut :

$$
\text { tak ada yang lebih tabah }
$$

$$
\text { dari hujan bulan juni }
$$




\section{dirahasiakannya rintik rindunya}

\section{kepada pohon berbunga itu}

Tokoh yang diimajinasikan dalam puisi tersebut ditransformasikan ke bentuk novel sebagai Sarwono dan Pingkan yang merupakan tokoh utama dalam novel $H B J$ karya Sapardi Djoko Damono.

Penambahan tokoh lain yang memperkuat cerita pada novel $H B J$ meliputi : Toar Pelenkahu, Budiman, Eric Patiasina, Prof. Ahmad, ibu Hartini, pak Pelenkahu, Ibu Hadi dan Pak Hadi. Tokoh-tokoh tersebut merupakan penambahan yang membuat serangkain cerita dalam novel menjadi utuh, sedangkan dalam puisi imajinasi pembaca sangat luas dan tokohnya hanya tergambarkan terbatas, hujan dan pohon berbunga.

Latar/setting yang tergambarkan pada novel memberikan gambaran jelas tempat di mana terjadinya peristiwa. Penambahan tempat ini dimaksudkan untuk memperjelas pembaca bahwa cerita benar-benar terjadi nyata. Tidak sepertihalnya puisi yang bersifat imajinatif, tempat kejadian tidak digambarkan dengan jelas, hanya ada dalam imajinasi masing-masing pembaca, bahwa pada puisi " $H B J$ " menggambarkan latar hujan pada bulan juni.

Latar/setting dalam novel meliputi : setting tempat, setting waktu, dan setting budaya. Yang masing-masing unsur tidak digambarkan dengan jelas pada puisi namun dijelaskan dengan gamblang pada novel.

Alur yang disusun pada novel merupakan pengembangan dari pengarang, karena dalam puisi sebagai karya aslinya tidak terdapat alur. Alur dalam novel merupakan penambahan sebagai unsur yang harus ada dalam karya sastra novel. Alur menggambarkan jalannya cerita, setiap karya sastra yang bersifat naratif atau bercerita memiliki unsur alur. Sehingga pengembangan alur pada novel memang ada. Alur pada novel $H B J$ menggunakan alur campuran. Alur campuran bersifat bolak-balik, sehingga cerita yang disajikan bisa bersifat maju dan kembali lagi pada masa sebelum cerita.

Sudut pandang yang tergambar pada novel merupakan cara penyajian cerita yang menggunakan sudut pandang persona ketiga, gaya "dia”, narator adalah seseorang yang di luar cerita yang menampilkan tokoh-tokoh cerita dengan menyebut nama, atau kata gantinya; ia, dia, mereka. Nama-nama tokoh cerita, khususnya yang utama, kerap atau terus-menerus disebut, dan sebagai variasi dipergunakan kata ganti. Hal ini yang akan 
mempermudah pembaca untuk mengenal siapa tokoh yang diceritakan atau siapa yang bertindak.

Sudut pandang persona ketiga ini merupakan gambaran pembacaan puisi yang terbentuk. Pada puisi yang terbaca terlihat dua tokoh yang timbul, kemudian digambarkan dalam novel dengan cara orang ketiga sebagai pencerita atau narator.

\section{Penggantian}

Dalam novel ditemukan beberapa peristiwa yang memang mampu mengambarkan dengan jelas maksud dari puisi " $H B J$ ", namun dalam novel penyampaiannya lebih jelas dalam mengambarkannya. Pengantian yang dimaksud berupa pendeskripsian, pengambaran tokoh, pengambaran setting, pengambaran alur, dan pengantian adegan. Sebagai contoh tokoh yang disamarkan dalam puisi, pada kutipan Hujan dan Pohon berbunga/Dirahasiakannya.../Dihapusnya.../ Dibiarkannya... tergambar bahwa orang ketiga yang dimaksudkan sebagai Sarwono dan Pingkan; Sifat arif, bijak dan tabah sebagai gambaran karakter tokoh Sarwono.

\section{Pelepasan}

Berkaitan dengan penambahan, maka pelesapan terjadi pada puisi dalam beberapa unsur: tokoh-tokoh tambahan yang tergambar pada novel (Toar, Pak Hadi, Ibu Hadi, Ibu Hartini, Budiman), alur dalam puisi tidak tergambar dengan jelas, sudut pandang, dan latar/setting. Dapat dimaklumi karena struktur dan unsur penyusun yang berbeda menyebabkan perbedaan keduanya.

Penguraian di atas memberikan gambaran penuh terhadap perubahan yang terjadi dari puisi ke novel HBJ karya Sapardi Djoko Damono. Dapat dikatakan novel merupakan hasil dari alih wahana dengan proses transformasi yang tetap menjadi karya sastra baru yang berbeda dari karya sastra aslinya yang berupa puisi. Hal ini sesuai dengan ungkapan Damono yang mengatakan alih wahana pasti menghasilkan jenis kesenian yang berbeda (Damono, 2014:46).

Selanjutnya Damono mengatakan bahwa sebuah teks, apa pun wujudnya, pada hakikatnya 'hanyalah' merupakan himpunan teks-teks lain yang ada sebelumnya. Kaitan- 
kaitan antara teks-teks itulah yang disusun menjadi makna oleh penerimanya : pembaca atau penonton (Damono. 2011-b).

Puisi yang ada dikembangkan dan dihimpun menjadi serangkaian cerita yang utuh berupa novel. Puisi adalah media yang sama sekali berbeda dengan novel. Puisi didominasi dengan bahasa kiasan yang memiliki sifat imajinatif. Imajinasi yang dibangun oleh penulisan puisi tentu akan berbeda dengan imajinasi yang dibangun dalam penulisan novel. Dengan demikian, pemabaham pembaca puisi dan pembaca novel terhadap makna cerita yang disampaikan dapat sama ataupun justru berbeda.

Imajinasi pada puisi akan berubah ketika ditransformasikan menjadi novel, karena esensi cerita yang semula pada puisi memberikan gambaran imajinasi yang sangat luas sedangkan pada novel sudah digambarkan dengan jelas oleh penulisnya. Sehingga dengan kata lain sifat imajinasi pembaca akan dibatasi ketika membaca novelnya dibandingkan ketika membaca puisinya. Perubahan tersebut menimbulkan perubahan-perubahan mendasar terhadap kedua karya sastra, sehingga dapat dikatakan bahwa novel $H B J$ karya Sapardi Djoko Damono merupakan karya baru.

\section{Simpulan}

Transformasi puisi "Hujan Bulan Juni" ke novel menyebabkan perubahan pada struktur. Meskipun mengalami perubahan, transformasi menjadi novel cenderung mampu mempertahankan imajinasi, inti cerita, dan pesan yang dibawakan dalam puisi. Imajinasi pembaca pada puisi tergambarkan dengan jelas terlebih pada novel. Puisi yang bersifat imajinatif ditafsirkan dengan penggambaran yang jelas pada novel. Unsur yang masih tetap menjadi pengikat di antara keduanya adalah tema dan amanat.

Perubahan yang digambarkan meliputi diksi pada kata hujan dan pohon berbunga digambarkan menjadi Sarwono dan Pingkan dalam novel. Pembaitan pada puisi diubah oleh pengarang menjadi alur cerita dalam novel. Citraan atau daya penangkapan indera pada puisi digambarkan sebagai latar/setting dalam novel. Bahasa figuratif diuraikan dalam novel sebagai sudut pandang persona ketiga dalam novel.

Penulis, Sapardi Djoko Damono, melalui proses transformasi " $H B J$ " seolah ingin menegaskan tujuan untuk lebih menghidupkan karya aslinya. Proses ini memberikan wahana yang berbeda sehingga membuat karya aslinya tetap hidup dan bertransformasi dalam format karya sastra baru. 


\section{Daftar Pustaka}

Buwono Budiastyo, Bakti. 2010. "Telegram Karya Putu Wijaya Transformasi dari Novel Menjadi Skenario Film". Skripsi S1 Sastra Indonesia Universitas Diponegoro Semarang.

Damono, Sapardi Djoko. 2013. Hujan Bulan Juni. Jakarta: Editum (Sepilihan Sajak).

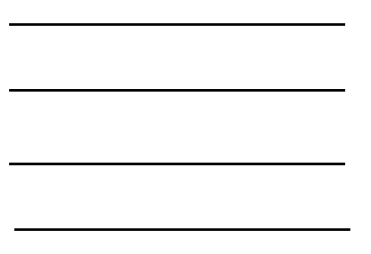
2015. Hujan Bulan Juni. Jakarta: PT Gramedia Pustaka Utama 2014. Alih Wahana. Jakarta: Editum. 2013. Sastra Bndingan. Jakarta: Editum.

Bahasa.

2005. Pegangan Penelitian Sastra Bandingan. Jakarta: Pusat

Depdiknas. 2008. “Kamus Besar Bahasa Indonesia”. Jakarta: Pusat Bahasa.

Eneste, Pamusuk. 1991. Novel dan Film. Jakarta: Nusa Indah.

Hawkes. 1978. Structuralism and Semiotics. London : Methuen \&amp; Co. Ltd.

Herwan, FR. 2005. Apresiasi dan Kajian Puisi. Serang: Gerage Budaya.

J. Waluyo, Herman. 2003. Apresiasi Puisi. Jakarta. PT Gramedia Pustaka Utama.

Koentjaraningrat. 1977. Model-model Penelitian Masyarakat. Jakarta : PT Gramedia Pustaka Utama.

Noor, Redyanto. 2010. Pengantar Pengkajian Sastra. Semarang: Fasindo.

2014. "Penelitian Sastra Bandingan, Prinsip Dasar, Teori dan Metode". Diktat Kuliah Sastra Bandingan FIB Universitas Diponegoro Semarang.

Nurgiyantoro, Burhan. 2010. Teori Pengkajian Fiksi. Yogyakarta: Gadjah Mada University Press.

Pangutami, Tantri. 2014. "Transformasi Novel Ronggeng Duku Paruk ke Film Sang Penari”. Skripsi S1 Sastra Indonesia Universitas Diponegoro Semarang.

Pradopo, Rachmat Djoko. 1987. Pengkajian Puisi. Yogyakarta: Gadjah Mada University Press.

2009. Pengkajian Puisi. Yogyakarta: Gadjah Mada University Press.

Pratamanti, Enggar Dhini. 2014. "Komikalisasi Novel $5 \mathrm{Cm}$ : Transformasi dan Penyebabnya". Tesis Megister Susastra Universitas Diponegoro Semarang.

Priyantini, Yuli. 2016. "Transformasi Kumpulan Cerita Madre ke dalam Film Sebuah Kajian Bandingan". Skripsi S1 Sastra Indonesia Universitas Diponegoro Semarang.

Teeuw. 1984. Sastra dan Ilmu Sastra: Pengantar Teori Sastra. Jakarta: Dunia Pustaka Jaya.

Wellek, Rene \& Warren, Austin. 2013. Teori Kesusastraan. Jakarta : PT Gramedia Pustaka Utama. 